\title{
Construyendo la democracia. Tardofranquismo, transición política y la cuestión autonómica en la provincia de León (1962- 1984).
}

\section{David MARTínEZ PÉREZ \\ Director: Dr. Francisco Carantoña Álvarez \\ Tesis doctoral defendida el 28 de enero de 2016}

Esta investigación comienza con un análisis demográfico y económico de la provincia durante la dictadura franquista. Para posteriormente explicar las características de la oposición antifranquista en el ámbito leonés, en donde destacó el PCE y la acción católica obrera. En la etapa final del franquismo comenzaron a abrirse lentamente espacios democráticos, entre los que cabe destacar el IV congreso nacional de la abogacía española (1970) y la oposición a la instalación de la central nuclear de Valencia de don Juan (1975). La conflictividad laboral resultó fundamental durante el tardofranquismo. Para poder conocerla se organizó en diversos períodos, que comenzaban con la oleada huelguística minera de 1962. Después de una etapa de calma, la crisis de la minería y la elaboración de los convenios colectivos contribuyeron al incremento de la disrupción laboral entre 1968 y 1971. Posteriormente disminuyó el número de conflictos en la provincia, pese a que se incrementó en el ámbito estatal.

El siguiente apartado explica la evolución de la Transición democrática en León. Resultaron fundamentales en este aspecto la configuración de las asociaciones políticas (todavía franquistas), la organización de los grupos de la oposición y el surgimiento de los nuevos movimientos sociales (feminismo o asociaciones vecinales). Asimismo se investigaron los resultados del referéndum de la ley para la reforma política. Que evidenciaron la diferenciación entre zonas abstencionistas, tal vez cercanas a la oposición y favorables al voto afirmativo. En esta etapa la conflictividad sociolaboral se incrementó y extendió a sectores antes tranquilos como la agricultura o la construcción. Resultaron esenciales las primeras elecciones democráticas, que tuvieron lugar en junio de 1977, y que mostraron la importante victoria de la UCD, que se repitió en los comicios de 1979, tanto legislativos como municipales. El apoyo de la mayoría de los partidos políticos a la constitución de 1978 explica el éxito de los sufragios afirmativos en ese referéndum, pero en pequeñas poblaciones del sur y este provincial la abstención y los votos en contra fueron destacados.

Finalmente se indagó sobre la cuestión autonómica en León. Se partió para ello de 
la evolución de los regionalismos en la provincia desde el siglo XIX hasta la dictadura franquista. La evolución de la organización territorial de España durante la Transición propició la aparición de organizaciones e instituciones regionales. Cabe señalar a la alianza regional de Castilla y León, el instituto regional de estudios castellano-leoneses y el grupo autonómico leonés. Como hechos reseñables se encontraron las manifestaciones a favor de la autonomía leonesa, y el cambio de posición de la UCD y el PSOE en 1980 a favor de la entrada en Castilla y León. Mientras la autonomía se consolidaba en La Rioja y Cantabria, en León no se realizó ningún trabajo legislativo, la responsabilidad, por tanto, fue de buena parte de la ciudadanía y de algunos políticos. Sin embargo, cuando el mapa autonómico estaba cerrado, se produjo una fuerte reacción de los grupos conservadores a favor de la autonomía leonesa, lo que contribuyó a que aumentara el volumen de las movilizaciones. Pero la sentencia del Tribunal Constitucional en 1984 que incluía a León dentro de la autonomía de Castilla y León generó una enorme frustración en el movimiento leonesista.

La economía de posguerra en la provincia de León (1937-1953): El Servicio Nacional del Trigo, los molinos y las fábricas de harinas. Los años del hambre y del estraperlo.

Javier ReVIlla CASAdo

Director: Dr. D. José Javier Rodríguez González

Tesis doctoral defendida el 19 de enero de 2016

El objetivo principal de esta Tesis Doctoral ha sido investigar la economía agrícola y sus industrias transformadoras -especialmente los aspectos vinculados al trigo, la harina y el pan-, en la provincia de León y para el período de la posguerra franquista. Así, documenta a través de fuentes archivísticas la dura realidad social de aquellos años y la respuesta al intervencionismo estatal de la producción triguera, hecho que supuso también un absoluto control sobre la harina y el pan (racionado hasta 1952).

Una de las principales conclusiones obtenidas ha sido la comprobación de que, pese al imperioso intento de control estatal -tanto de las producciones agrícolas, como de su transporte y depósito, así como de su transformación para el consumo-, las instituciones creadas por el franquismo fueron incapaces de conseguirlo en los años estudiados. No lo lograron eficientemente ni el Servicio Nacional del Trigo, ni la 